\title{
Kanada (Ontario) ve Türkiye Sosyal Bilgiler Öğretim Programlarının Vatandaşlık Eğitimi Açısından Karşılaştırılması ${ }^{1}$
}

\author{
Doç. Dr. İlker DERE* \\ Necmettin Erbakan Üniversitesi, Ahmet Keleşoğlu Eğitim Fakültesi, Türkçe ve Sosyal Bilimler Bölümü, \\ Konya / Türkiye, idere@erbakan.edu.tr, ORCID: 0000-0003-0993-7812

\section{Şerife Nur AKDENIZ} \\ Necmettin Erbakan Üniversitesi, Eğitim Bilimleri Enstitüsü, Türkçe ve Sosyal Bilimler Bölümü, \\ Konya / Türkiye, nurakdeniz8@outlook.com, ORCID: 0000-0002-7586-7122
}

\section{$\ddot{O} z$}

Karşılaştırmalı eğitim çalışmaları, çeşitli ülkeler arasında pedagojik bilgi alışverişini sağlamaktadır. Dünyanın birçok ülkesinde aynı isimle okutulan sosyal bilgiler dersiyle ilgili gelişmeler, Türkiye'yi yakından ilgilendirmektedir. Bu araştırma, sosyal bilgiler dersi okutulan ülkelerden biri olan Kanada’nın (Ontario) eyaleti ile Türkiye sosyal bilgiler öğretim programlarını vatandaşlık eğitimi açısından karşılaştırmayı amaçlamaktadır. Doküman incelemesi yöntemiyle yapılan araştırmanın veri kaynakları, 2018 Ontario ve Türkiye sosyal bilgiler öğretim programlarıdır. Bu iki örneklem belirlenmeden önce Kanada'daki tüm eyaletlerin sosyal bilgiler öğretim programları incelenmiştir. İnceleme sonunda Ontario eyaleti ve Türkiye'de uygulanan sosyal bilgiler öğretim programlarının karşılaş-

\footnotetext{
${ }^{1}$ Bu çalışma, 07-09 Kasım 2019 tarihleri arasında Ankara Üniversitesi'nde gerçekleştirilen "8. Uluslararası Sosyal Bilgiler Eğitimi Sempozyumu"nda sözlü bildiri olarak sunulmuştur.

* Sorumlu Yazar. Tel: +90 (332) 2210500

Makale Tarih Bilgisi. Gönderim: 02.01.2020, Kabûl: 11.04.2020, Basım: Haziran, 2021.
}

(C) 2021. Kalem Eğitim ve Sağlık Hizmetleri Vakfı. Bütün Hakları Saklıdır. 
tırılmasına karar verilmiştir. Programlardan elde edilen veriler, betimsel analiz yöntemiyle değerlendirilmiştir. Araştırma sonuçları, Türkiye sosyal bilgiler öğretim programında vatandaşlık eğitimi konularının "Etkin Vatandaşlık" öğrenme alanında toplandığı, Kanada (Ontario) öğretim programının ise tüm dersleri kapsayacak özel bir vatandaşlık çerçevesine sahip olduğunu göstermektedir. Bunun yanında Ontario programında yerel, ulusal ve küresel düzeyde vatandaşlık vurgusu yapılırken, Türkiye programında vatandaşın nitelikleri ve sorumlulukları daha çok Türk vatandaşlığı kavramı içerisinde yer almıştır. Ancak her iki programın da toplumda ve hızla değişen dünyada bilgi sahibi, bilgiyi üreten, eleştirel düşünebilen, problem çözebilme ve etkili iletişim kurabilme becerisine sahip aktif ve sorumlu vatandaşlar yetiştirmeyi amaçladığı sonucuna varmak mümkündür.

Anahtar Kelimeler: Sosyal bilgiler öğretim programı; Kanada; Türkiye; Karş1laştırmalı eğitim; Vatandaşlık eğitimi.

\title{
Comparison of Canada (Ontario) and Turkey Social Studies Curriculum with Respect to the Citizenship Education
}

\begin{abstract}
Comparative educational studies provide pedagogical information exchange between various countries. The developments related to social studies courses that is taught with same name in many countries are more likely to produce interests for Turkey. This research aims to compare Social Studies Curriculums of state of Ontario and Turkey in term of citizenship education. The social studies teaching programs of all Canadian states were examined and these two samples were selected for comparison. Data sources of the research that is conducted with document review method are 2018 Ontario and Turkey social studies curricula. After the investigation, it was decided by the researchers that social studies programs of Ontario and Turkey will be compared. The data obtained from the programs were evaluated with descriptive analysis. Research results have shown that while citizenship education topics in Turkey social studies curriculum are collected under "Active Citizenship" learning outcome, Canadian curriculum (Ontario) has a special definition of the citizenship which covers all classes. In addition, while The Ontario program has an emphasis of the citizenship on local, national and global levels, the attributes and responsibilities of citizens in Turkish curriculum are mostly defined within the concept of Turkish citizenship. However, it is possible to conclude that both programs aim to raise active and responsible citizens who are knowledgeable, produce knowledge, think critically, solve problems and
\end{abstract}


communicate effectively.

Keywords: Social studies curriculum; Canada; Turkey; Comparative education; Citizenship education.

\section{Extended Summary}

\section{Purpose}

Studies that compare education systems allow pedagogical information exchange among countries. The developments related to the Social Studies course taught under the same name in many countries of the world are of particular concern to Turkey. Social Studies course is taught in Turkey as well as the most culturally diverse countries such as the USA, Australia, and Canada. The Social Studies course offered in these countries equips students with the knowledge and skills necessary for citizenship education, which makes it important to examine the content of citizenship education in related countries. A thorough review of the relevant literature shows that education systems, particularly of Canada and Turkey, have been compared in terms of various dimensions. However, related studies have compared only to a limited extent the education systems of both countries in terms of citizenship education. Furthermore, to the best of our knowledge, no studies have so far been conducted to compare Canada and Turkey's social studies curricula in terms of citizenship education. This study, which has been designed based on this gap in the literature, aims to comparatively examine the 2018 Canada (Ontario) Social Studies Curriculum and 2018 Turkey Social Studies Curriculum in terms of citizenship education. We hope that this comparison made on the basis of curricula will contribute to the developments and discussions about citizenship education in Turkey.

\section{Method}

The data sources of this research, which was conducted using the document analysis method, are the 2018 social studies curricula of Ontario and Turkey. The originality of the curricula accessed from the websites of the national education ministries of both countries was checked. Then, the data obtained from the curricula were interpreted by the descriptive analysis method.

\section{Results}

Our investigations have revealed that the Ontario social studies curriculum offers a particular citizenship framework for citizenship education, and the objectives of citizenship education have been determined based on 
this framework. On the other hand, the Turkish curriculum does not offer any citizenship framework and the objectives of citizenship education are given among the objectives of the Social Studies course. Besides, we have found that the Ontario curriculum contains topics related to citizenship education under "Heritage and Identity" and "People and Environments" themes (grades 1-6) and in History and Geography courses (grades 7-8). On the other hand, in the Turkish curriculum, in grades 4-7, topics related to citizenship education are taught directly under the "Effective Citizenship" theme and indirectly under other themes. In addition, it is concluded that both curricula aim to teach values of "equality, justice, respect, freedom, and responsibility" as well as raise individuals who can "empathize, think critically, make decisions, perceive time and chronology, and collaborate." Finally, the most important difference between the two curricula is related to global and national citizenship topics.

\section{Discussion}

Although the education systems of countries differ in some ways, perhaps their most important common goal is to raise good citizens (Yavuz, Duman and Karakaya, 2016). For example, while the Ontario curriculum emphasizes local, national and global citizenship, the Turkish curriculum mainly underlines the citizenship of the Republic of Turkey. As a reason for this, Öztürk and Zayimoğlu-Öztürk (2013), who compared Ontario and Turkey's social studies curricula in terms of their objectives, suggested the structure of the Turkish curriculum that focuses on Turkey's national interests. The greater emphasis on global citizenship in the curriculum of Canada, a country of immigrants, is the result of a need for Canada, as noted by Massey (2014).

\section{Conclusion}

The results of our research show that citizenship education programs offered in social studies curricula of the two countries with different cultural structures have differences and similarities. Both curricula aim to raise active and responsible citizens who can ask questions, construct knowledge, and think critically and who have problem-solving and effective communication skills in this rapidly changing world. Besides, both curricula have different approaches, especially towards national and global citizenship. In this context, it would be advisable to propose the introduction of the global citizenship topic in the Turkish curriculum in a way that supports its local, national, and 
global dimensions. In particular, the scope of the topics under the 'global connections' learning area in the Turkish curriculum should be expanded and associated with current events.

\section{Giriş}

1700'lerden itibaren sürekli göç alan ve dolayısıyla birçok etnik grubu barındıran Kanada, çokkültürlülük politikalarını uygulamayı resmen kabul eden dünyadaki ilk ülke olmuştur (Erzurumlu, 2008; Özensel, 2012). 1988'de Kanada'da kabul edilen yasayla, kültürel ve etnik çeşitliliğinin Kanada mirasının ve kimliğinin temel bir özelliği olduğu ve ülkenin geleceğini şekillendirmede önemli bir kaynak olduğu vurgulanmıştır. İlgili yasayla, çeşitli milletlerden bireylerin ve toplulukların tam ve eşit katılımını teşvik etmekle birlikte, bu katılımın önündeki olası herhangi bir engelin ortadan kaldırılması amaçlanmıştır. Yasa önünde tüm bireyler eşit görülmüş; sosyal, kültürel, ekonomik ve politik kurumların Kanada'nın çok kültürlü karakterine saygılı ve kapsayıcı olması teşvik edilmiştir (Canadian Multiculturalism Act, 1988).

Bilindiği gibi, çok kültürlü bir toplumda, toplumların birleşebilmesi ve farklılıkların kabul edilebilmesi, vatandaşların toplumda aktif ve etkili olmasına bağlıdır. Topluluğa katılım konusunda vatandaşların atılabileceği ilk adım, içinde yaşadıkları toplum arasında bağlantı kurabilmektir (Heinhorst, 2008). Bu bağlantının kurulmasında en etkin rolü, vatandaşlık eğitimi üstlenmektedir. Bu kapsamda vatandaşlık eğitimi, farklı felsefi, politik ve ideolojik bakış açıları ve pedagojik yaklaşımları, amaçları ve uygulamaları içeren kapsamlı bir eğitimdir. Bu felsefi ve pedagojik yaklaşımlar üzerine inşa edilen vatandaşlık eğitimiyle karşılıklı saygı, sorumluluk ve bağlılık; yerel, ulusal ve küresel topluluklarda vatandaşlık için temeldir. Yani vatandaşlık eğitimi, sosyal, politik, kültürel ve ekonomik alanlarda yerel, ulusal ve uluslararası boyutları ilgilendiren çok yönlü bir eğitimi kapsamaktadır (Hébert, 2009; Merey, Karatekin ve Kuş, 2012; Schugurensky ve Myers, 2003). Bu çok yönlü eğitim, etkili vatandaşlar yetiştirilmesini sağlar. Etkili bir vatandaşlık eğitimi bireylerin; aktif olmasını, küresel düşünebilmesini, gerekli bilgiye ulaşarak elde ettiği bilgileri bilişsel süreç içerisinde değerlendirebilmesini, siyasal ve sosyal olaylara katılarak ve demokratik değerleri benimseyebilmesini sağlayacak niteliklere ve yeterliklere sahip olmalarını amaçlar (Ersoy, 2007).

$\mathrm{Bu}$ niteliklere ve yeterliklere sahip bir vatandaş modeli oluşturmak isteyen ülkeler, eğitim sistemlerinde bu amaca yönelik dersler okutmaktadır. 
ABD, Avustralya, Yeni Zelanda, Kanada, Finlandiya, Fransa ve Türkiye'de ülkeler vatandaşlık eğitimi için gerekli olan bilgi ve becerileri, sosyal bilgiler dersleri kapsamında öğrencilere kazandırmaktadır (Kafadar, Öztürk ve Katılmış, 2018; Kuş ve Aksu, 2017; Özkaral, 2015). Sosyal bilgiler dersi ile öğrencilere yapılandırmacı bir yaklaşım içinde farklı bakış açılarını sentezleyerek kendi fikirlerini oluşturabilme firsatı sunulur. Sosyal bilgiler dersi ile edindikleri bilgi ve birikimlerini yaşama geçirebilecek yeterlikleri kazanan öğrenciler, bir başkasının dünya hakkındaki görüşünü pasif bir şekilde almaktan ziyade, dünyadaki farklı bakış açılarını ve demokratik değerleri benimsemiş vatandaşlar olarak, topluma uyum sağlayıp dünyayı dönüştürmek için nasıl hareket edebilecekleri hakkında kişisel olarak anlamlı bir görüş oluştururlar (Arslan, 2007; Merey, 2012; Ross, 2001). Bu bağlamda sosyal bilgilerin amacı, vatandaşları toplumda sorumlu ve aktif kılmaktır. Bu gerekçeyle öğrencilerin topluma katılımını sağlamayı teşvik eden bir sosyal bilgiler müfredatı oluşturabilmek oldukça önemlidir (Ross, 2001).

Eğitim sistemi içerisinde sosyal bilgiler dersine önemli ölçüde yer veren Kanada, federal bir sistemde on eyalet hükümetinden ve üç kuzey bölgesinden oluşmaktadır (Özensel, 2012). İlgili eyaletlerin sosyal bilgiler öğretim programları vatandaşlık eğitimi açısından incelendiğinde, Ontario eyaletinin sosyal bilgiler öğretim programında, Kanada'nın çokkültürlülük yasasını destekleyen kapsayıcı ve eşitlik ilkesine, bunun yanı sıra programdaki tüm konuları kapsayacak şekilde özel bir "Vatandaşlık Eğitimi Çerçevesi”ne (Ontario Ministy of Education [OMOE], 2018) yer verildiği görülmektedir.

\section{Ontario'da Sosyal Bilgiler ve Vatandaşık Eğitimi}

Bir değişim ve sosyal uyum aracı olarak Ontario eğitim sistemi; adalet, eşitlik ve herkese saygı gibi demokratik değerleri desteklemeyi ve yansıtmayı amaçlamaktadır (OMOE, 2009). Ontario'daki ilköğretim okulları, yüksek kaliteli öğrenmeyi desteklemek için çaba sarf ederken, her öğrenciye kendi güçlü yönlerine ve gereksinimlerine en uygun şekilde öğrenme firsatı sunmaktadır. Ontario müfredatı, yaşına ve seviyesine uygun bir öğrenme programı aracılığıyla her öğrencinin potansiyelinden yararlanmasına yardımcı olmak için tasarlanmıştır (OMOE, 2018). Ontario Millî Eğitim Bakanlığ1, "Her çocuğu destekle, her öğrenciye ulaş" sloganı ile hareket etmektedir (OMOE, 2016).

$\mathrm{Bu}$ bağlamda hazırlanan Ontario Sosyal Bilgiler Öğretim Programı, öğrencilerin kapsayıcı bir topluma değer veren eleştirel düşünen ve bilgili 
vatandaşlar olmalarının yanı sıra, sorunları çözme ve önemli gelişmeler, olaylar ve konularla ilgili fikir ve kararları iletme konusunda gerekli becerilere sahip olmalarını sağlamayı amaçlamaktadır (OMOE, 2018). İlgili programda, 1-6. sınıflar için sosyal bilgiler dersinin, 7. ve 8. sınıflar için tarih ve coğrafya derslerinin beklentilerini ve kazandırılmak istenen bilgi ve becerileri tanımlanmıştır (OMOE, 2016; OMOE, 2018).

Ontario sosyal bilgiler öğretim programının en önemli parçalarından birisi, vatandaşlık eğitimidir. Sosyal bilgiler içerisinde vatandaşlık konuları, "Vatandaşlık Eğitimi Çerçevesi” kapsamında sunulmuştur. Bu çerçeve, vatandaşlık eğitiminin temel unsurlarını bir araya getirmektedir. Ayrıca sosyal bilgiler öğretim programı içerisinde "Yerlilerin Eğitim Stratejisi"ne de yer verilmiştir. "Eski Aborjin Eğitim Stratejisi" olarak da bilinen bu strateji ile tüm potansiyellerini gerçekleştirmeleri için ilk ulus, Métis ve Inuit halklarına mensup öğrencilere destek verilmektedir. Ontario Millî Eğitim Bakanlığı, yerlilerin eğitimiyle öğrenci başarısını ve refahını iyileştirmeyi ve yerli öğrenciler ile tüm öğrenciler arasındaki başarı farkını kapatmayı amaçlamıştır (OMOE, 2019).

Sosyal bilgiler dersi içerisinde vatandaşlık eğitimine büyük ölçüde yer veren Ontario eğitim sisteminin yanı sıra Türkiye eğitim sistemi içerisinde de vatandaşlık eğitiminin sosyal bilgiler dersi kapsamında önemli bir yeri vardır.

\section{Türkiye'de Sosyal Bilgiler ve Vatandaşık Eğitimi}

Türkiye'de 2005 yılından itibaren yapılandırmacı ve disiplinler aras 1 yaklaşımın benimsendiği programlar uygulanmaya başlanmıştır. 2005 öğretim programlarında "vatandaşlık eğitimi" ara disiplinler aracıllğıyla ilköğretim derslerinin içerisine dağıtılarak öğretilmiştir (Merey, Karatekin ve Kuş, 2012). 2018 y1lında yenilenen öğretim programları ile ilkokul 1-3. sınıflar için hazırlanan Hayat Bilgisi Dersi Öğretim Programı'yla temel yaşam becerilerine sahip, kendini tanıyan, sağlıklı ve güvenli bir yaşam süren, yaşadığı toplumun değerlerini özümseyen, doğaya ve çevreye duyarlı, araştıran, üreten ve ülkesini seven bireyler yetiştirmek amaçlanmıştır (Millî Eğitim Bakanlığı [MEB], 2018a). 4. sınıflar için hazırlanan İnsan Hakları, Yurttaşlık ve Demokrasi Dersi Öğretim Programında ise; "İnsan Olmak", "Hak, Özgürlük ve Sorumluluk", "Adalet ve Eşitlik", "Uzlaşı", "Kurallar" ve "Birlikte Yaşama" olmak üzere altı ögrenme alanından oluşmaktadır (MEB, 2018b). İlkokul ve ortaokul 4-7. sınıflar için hazırlanan Sosyal Bilgiler Öğretim Programı'nda ise vatandaşlık eğitimi, "Etkin Vatandaşlık" öğrenme alanı ile doğrudan, diğer 
öğrenme alanları ile dolaylı olarak yapılandırılarak sunulmuştur (MEB, 2018c).

2018'de yenilenen sosyal bilgiler öğretim programı ile özellikle insan hakları, vatandaşlık ve demokrasi konuları disiplinler arası yaklaşımla ele alınmıştır. Bu yaklaşımla öğrencilerin, insan hakları, ulusal egemenlik, demokrasi, laiklik, cumhuriyet kavramlarının tarihsel süreçlerini bugünkü Türkiye'ye etkilerini kavrayarak, yaşamlarını demokratik kurallara göre düzenlemeleri amaçlanmaktadır. Bunun yanı sıra "Türkiye Yetkinlikler Çerçevesi (TYÇ)" içerisinde belirlenen yetkinlikler sayesinde öğrencilerin gerekli bilgiler ile donatılarak aktif ve demokratik katılım kararlılığ tam katılımlarını sağlama teşvik edilmektedir (MEB, 2018c).

Aktif ve demokratik katılımı sosyal bilgiler öğretim programının odağına alan Türkiye, dünyadaki farklı ülkelerde okutulan sosyal bilgiler dersleriyle de yakından ilgilenmektedir. Farklı ülkelerin sosyal bilgiler ders içeriğine, öğretim programlarına ve ders odaklarına dikkat ederek sosyal bilgilerin gelişim sürecini inceleyen çeşitli karşılaştırmalı eğitim çalışmaları ile farklı pedagojik bilgi alışverişleri sağlanmakta ve Türkiye'deki sosyal bilgiler eğitimi çalışmalarına katkılar sunulmaktadır.

\section{Karşılaştırmalı Eğitim Çalışmaları}

Alanyazında Türkiye ile farklı ülkelerin sosyal bilgiler öğretim programlarını karşılaştıran çeşitli çalışmalar bulunmaktadır. İlk olarak, Alkın (2007), İngiltere ve Türkiye'de ilköğretim programlarında yer alan vatandaşlık eğitimini incelediği çalışmasında, İngiltere'de vatandaşlık eğitimi politikalarını eğitim bakanlığının yanı sıra vatandaşlık eğitimi ile ilgili kurum ve grupların etkileyebildiğini ortaya koymuştur. Buna karşın Türkiye'de örgün eğitim kapsamında vatandaşlık eğitim programını yalnızca Millî Eğitim Bakanlığı'nın belirlediğini ortaya koymuştur.

İkinci çalışmada İnci (2009), Türkiye ile Kanada (Ontario), İrlanda, Amerika Birleşik Devletleri (New York ve Kaliforniya), Finlandiya ve Yeni Zelanda sosyal bilgiler programlarını karşılaştırmıştır. Karşılaştırma sonunda ele alınan 6 ülke programının da hak ve sorumluluklarını bilen demokratik vatandaşlar ve eleştirel düşünebilen bireyler yetiştirmeyi amaçladığı görülmüştür. Bunun yanında diğer 5 programla Türkiye arasında en belirgin yaklaşım farkının, çokkültürlülük konusunda olduğu tespit edilmiştir.

Üçüncü çalışmada Merey, Karatekin ve Kuş (2012), Türkiye ve 
ABD'deki ilköğretim sosyal bilgiler eğitimini vatandaşlık eğitimi açısından literatüre dayalı olarak karşılaştırmasını yapmışlardır. Bu incelemede, Türkiye'de sosyal bilgilerde vatandaşlık eğitiminde verilen değerlerin daha çok bireysel ve toplumsal niteliklere sahip 'iyi insan' ve 'iyi vatandaş' yetiştirmeye yönelik olduğu, Amerika' da ise demokratik değerlerle ideal demokratik Amerikan toplum modelinin oluşturulmasını amaçlandığı görülmüştür.

Dördüncü çalışmada Öztürk ve Zayimoğlu-Öztürk (2013), 2004 Kanada (Ontario) Sosyal Bilgiler Öğretim Programı ile 2005 Türkiye Sosyal Bilgiler Öğretim Programını karşılaştırmışlardır. Çalışma sonunda, Türkiye programında temel öğeler olarak beceri, değer ve kavram öğretiminin öneminin vurguladığı, Ontario programında ise bu özelliklere değinilmediği vurgulanmıştır.

Son olarak Bektaş ve Zabun (2019), Türkiye'de okutulan insan haklar1, demokrasi ve yurttaşlık ile Fransa'da okutulan vatandaşlık ve ahlak eğitimi derslerinin öğretim programlarını vatandaşlık değerleri açısından karşılaştırmıştır. Araştırma sonucunda Fransa vatandaşlık eğitiminde en fazla adalet değerine, Türkiye programında özgürlük değerine yer verildiği görülmüştür.

Değinilen araştırmaların dışında Özkaral $(2015,2019)$, Bursa ve Çengelci-Köse (2017), Kafadar, Öztürk ve Katılmış (2018), Yavuz ve Özkaral (2019) tarafından çeşitli karşılaştırmalı çalışmalar yürütülmüştür. Alanyazındaki bu karşılaştırmalarda, programlar daha çok temel özellikleri ve değer eğitimi açısından incelenmiştir. Bunun yanında Kanada'yla ilgili yapılan bazı çalışmalarda kısmen vatandaşlık eğitimine ve vatandaşlık konularına yer verilmesine rağmen Kanada ve Türkiye sosyal bilgiler öğretim programlarının vatandaşlık eğitimi açısından detaylı bir karşılaştırılmasının yapılmadığı görülmüştür. Alanyazındaki bu eksiklikten yola çıkılarak tasarlanan bu çalışmanın amacı, 2018 Kanada (Ontario) Sosyal Bilgiler Öğretim Programı ile 2018 Türkiye Sosyal Bilgiler Öğretim Programını vatandaşlık eğitimi açısından karşılaştırmalı olarak incelemektir. Öğretim programları bazında yapılan bu karşılaştırmanın Türkiye'deki vatandaşlık eğitimine ilişkin gelişmelere ve tartışmalara katkı sağlayacağı düşünülmektedir. Çalışmanın amacına yönelik olarak şu sorulara cevap aranmıştır:

1) Programlarda yer verilen vatandaşlık eğitiminin amaçları nelerdir?

2) Programlarda vatandaşlık eğitiminin temel unsurları ve bileşenleri nelerdir?

3) Programlarda vatandaşlık eğitimi konuları nasıl bir dağılım göster- 
mektedir?

4) Programlarda vatandaşlık eğitimi kapsamında hangi değer ve becerilerin kazandırılması amaçlanmaktadır?

5) Programlarda vurgulanan vatandaşlık tipleri nelerdir?

\section{Yöntem}

\section{Araştırma Modeli}

$\mathrm{Bu}$ çalışmada kullanılan doküman incelemesi yöntemi, araştırılan olgu ya da olaylar hakkında bilgileri kapsayan yazılı materyallerin analizini içermektedir. Doküman incelemesi veya analizi, tek başına bir yöntem olarak veya diğer yöntemlerle birlikte kullanılabilmektedir (Yıldırım ve Şimşek, 2018). Bu çalışmada doküman incelemesiyle, karşılaştırılan programlara ulaşılmış ve karşılaştırmalı olarak değerlendirilmiştir.

\section{Karşılaştırmalı Eğitim}

Karşılaştırmalı eğitim, milli eğitim sistemlerinin ilk ve ortaöğretimi kapsayan kısmının, siyasal, sosyal ve kültürel etkenleri göz önünde bulundurarak inceleyen, sistemlerin benzerlikleri ve farklılıklarını tanımlamaya yardım eden, olguları açıklayan ve insanları eğitme yolları hakkında yararlı teklifler sunan bir alandır. Bu karşılaştırma sırasında dünyadaki eğitim sorunlarının benzerliği, oluşma şekilleri ve çözüm önerileri değerlendirilir. Bu değerlendirmeler, ülkelerin kendi eğitim sorunlarına aradığı çözümleri geniş bir bakış açısı içerisinde ele almasını ve çeşitli disiplinlerin birikimlerinden faydalanmasını sağlar (Erdoğan, 2003). Karşılaştırmalı eğitim çalışmaları; yatay, dikey, problem çözme, örnek olay, tanımlayıcı, açıklayıcı ve değerlendirici yaklaşım olmak üzere yedi şekilde yapılmaktadır (Delibaş, 2007). Bu yaklaşımlardan biri olan yatay yaklaşımda ilgili eğitim sistemlerinin öğeleri ayrı ayrı incelenir. Sonraki aşamada, benzerlikleri ve farklılıkları ortaya konulur (Yıldırım ve Türkoğlu, 2018). Bu araştırmada Kanada ve Türkiye sosyal bilgiler öğretim programlarının unsurlarının güncel durumlarını vatandaşlık eğitimi açısından karşılaştırmak için yatay yaklaşım kullanılmıştır.

\section{Veri Kaynakları}

Araştırmanın veri kaynaklarını, 2018 Kanada (Ontario) Sosyal Bilgiler Öğretim Programı, 2018 Türkiye Sosyal Bilgiler Öğretim Programı ve alanyazın çalışmaları oluşturmuştur. Veri kaynakları belirlenmeden önce, Türkiye ile karşılaştırılması yapılacak ülkeler incelenmiştir. Ardından çok kültürlü bir toplum yapısına sahip olan Kanada'nın, sosyal bilgiler öğretim programlarında vatandaşlık eğitimine ne ölçüde yer verdiği araştırılmıştır. On eyalet ve 
üç bölgeden oluşan ülkenin incelenen öğretim programları içerisinde Ontario eyaletinin sosyal bilgiler öğretim programında, Kanada'nın çokkültürlülük yasasını destekleyen kapsayıcı ve eşitlik ilkesine, bunun yanı sıra programdaki tüm konuları kapsayacak şekilde özel bir "Vatandaşl1k Eğitimi Çerçevesi”"ne yer verildiği görülmüştür. Bu gerekçeyle 2018 Ontario Sosyal Bilgiler Öğretim Programı ile 2018 Türkiye Sosyal Bilgiler Öğretim Programı'nın vatandaşlık eğitimi açısından karşılaştırılmasına karar verilmiştir. Böylece çalışmanın temel veri kaynakları belirlenmiştir.

\section{Verilerin Toplanması ve Analizi}

Doküman incelemesi genel bir yönerge ile "dokümanlara ulaşma, orijinalliği kontrol etme, dokümanları anlama, veriyi analiz etme ve veriyi kullanma" olarak beş aşamadan oluşabilmektedir (Yıldırım ve Şimşek, 2018, s.194). Bu doğrultuda verilerin toplanması ve analiz süreci aşağıda açıklanmıştır:

\section{Dokümanlara Ulaşma ve Orijinalliğini Kontrol Etme}

Araştırmanın temel veri kaynaklarını ülkelerin sosyal bilgiler öğretim programları ve ilgili alanyazın çalışmaları oluşturduğu için, Türkiye sosyal bilgiler öğretim programına Talim ve Terbiye Kurulu'nun internet sitesinden (TTKB, 2019), Ontario sosyal bilgiler öğretim programına ise eyaletin milli eğitim bakanlığ sitesinden (OMOE, 2019) ulaşılmıştır. Böylece dokümanların orijinallikleri kontrol edilmiştir.

\section{Dokümanları Anlama}

Elde edilen dokümanlar tek tek vatandaşlık eğitimi boyutunda incelenmiş, birbirleri ile karşılaştırmaları yapılmış ve belirli bir analiz taslağ oluşturulmuştur.

\section{Veriyi Analiz Etme}

Araştırmanın analizi, nitel analiz yöntemlerinden biri olan betimsel analiz yöntemi ile yapılmıştır. Bu yaklaşıma göre önceden belirlenmiş olan temalardan elde edilen veriler, özetlenerek yorumlanmaktadır. Böylece elde edilen bulguların okuyuculara düzenlenerek ve yorumlanarak sunulması amaçlanmaktadır. Bu sebeple veriler ilk olarak sistematik ve açık bir şekilde betimlenir. Daha sonra açıklanan ve yorumlanan betimlemelerin, sebep-sonuç ilişkisi içerisinde incelenmesi ile birtakım sonuçlara ulaşılmaktadır. Betimsel analiz "bir çerçeve oluşturma, çerçeveye göre verilerin işlenmesi, bulguların 
tanımlanması ve yorumlanması" olarak dört aşamayı içermektedir (Yıldırım ve Şimşek, 2018).

$\mathrm{Bu}$ araştırmada öncelikle vatandaşlık eğitimine ilişsin "amaçlar, temel unsurlar, temalara göre dağılım, değerler, beceriler ve yetiştirilmek istenen vatandaş tipi" boyutlarını içeren analiz çerçevesi oluşturulmuş, ardından bu çerçeveye göre veriler analiz edilmiştir. Analizler sonunda ulaşılan bulgular, betimlenmiş, yorumlanmış ve karşılaştırılmıştır. Ayrıca güvenirlik ve geçerlikle ilgili yapılan çalışmalara ek olarak araştırmacılar, verileri öncelikle birbirinden bağımsız, ardından birlikte analiz etmiş ve yorumlamışlardır.

Bunların yanı sıra kazanımlar doğrultusunda elde edilen bulgular için kazanımlar öğretim programlarında ifade edildiği şekilde kodlanmıştır. Ontario öğretim programında sosyal bilgiler, tarih ve coğrafya derslerindeki beklentiler "A ve B" olarak adlandırılan iki başlık halinde düzenlenmiştir. Bu başl1klar altında numaralandırılarak verilen başl1klar belirli bir genel beklenti ile ilgilidir (örn: A1). Genel beklentiler içerisindeki bilgi ve becerileri daha ayrıntılı bir şekilde ifade etmek için özel beklentiler düzenlenmiştir. Özel beklenti numarası, beklentinin ait olduğu başlığı ve ilgili genel beklentileri (örneğin: A1.1) tanımlanmıştır (OMOE, 2018b). Türkiye öğretim programında yer alan kazanımlar ise öğrenim alanlarına göre numaralandırılmıştır. Örneğin "SB.4.1.1." kodlamasında; "SB” ders kodunu, "4.” sınıf düzeyini, "1." öğrenme alanı numarasını, "1." kazanım numarasını ifade etmektedir (MEB, 2018c).

\section{Bulgular}

$\mathrm{Bu}$ bölümde, araştırmanın amacına yönelik sorulan sorularla karşılaştırmalı olarak incelenen programlardan elde edilen bulgular altı başlık altında yer almaktadir.

\section{Programların Vatandaşıı Eğitimi Amaçları Açısından Karşılaş- tırılması}

İlk olarak programlar, vatandaşlık eğitiminin amaçları açısından karŞılaştırılmıştır. Ontario öğretim programında vatandaşlık, "çeşitli topluluklardaki vatandaşların (yerel, ulusal ve küresel) haklarının ve bu haklarla ilgili rollerin, sorumlulukların ve eylemlerin anlaşılması" olarak tanımlanmıştır. Ayrıca programa göre vatandaşlık eğitimi, genel eğitimin önemli bir parçasıdır. Sosyal bilgiler, tarih ve coğrafya derslerinin müfredatlarında, öğrencilere sınıfta, okul içinde ve dışında, bulundukları çeşitli topluluklarda sorumlu 
ve aktif bir vatandaş olmayı öğrenmeleri için firsatlar vermek amaçlanmaktadır. Bunlarla birlikte öğrencilerin birçok topluluğa ve nihayetinde tümünün küresel topluluğa ait vatandaşlar olduklarını anlamalarına yönelik bir vatandaşlık eğitimi tasarlanmıştır (OMOE, 2018).

Buna karşın Türkiye öğretim programında herhangi bir vatandaş tanımına ve vatandaşl1k eğitimine ilişkin özel bir amaca yer verilmemiştir. Ancak dersin özel amaçlarından yola çıkılarak vatandaşlık eğitimiyle öğrencilerin, Türkiye Cumhuriyeti vatandaşı olarak vatanını ve milletini seven, haklarını bilen ve kullanan, sorumluluklarını yerine getiren, millî bilince sahip birer vatandaş olarak yetiştirilmesinin amaçlandığı söylenebilir (MEB, 2018c). Bu yönüyle hem yetiştirilmek istenen vatandaşın niteliklerine hem de vatandaşlık eğitiminin beklentilerine dikkat çekildiği görülmektedir.

\section{Programlarda Vatandaşlık Eğitiminin Temel Unsurları ve Bile- şenleri}

Bir diğer araştırma sorusu kapsamında programlar, vatandaşlık eğitiminin temel unsurları ve bileşenleri açısından karşılaştırılmıştır. Öncelikle Ontario öğretim programına bakıldığında, vatandaşlık eğitiminin özel bir çerçeveyle dört temel unsur üzerine oturtulduğu görülmüştür. Programda hazırlanan vatandaşlık eğitimi çerçevesi incelenmiş ve aşağıdaki Şekil 1'de sunulmuştur.

Şekil 1'de bulunan çerçevedeki dış daire, vatandaşlık eğitiminin dört ana unsurunu (aktif katılım, kimlik, nitelikler ve sosyal yapılar) içermektedir. İkinci dairede sorumlu vatandaşlıkla ilgili bilgi, beceri ve tutumları geliştirme yolları gösterilmektedir. Bu kapsamda öğrencilerin sosyal bilgiler, tarih ve coğrafya derslerindeki vatandaşl1kla ilgili kazanımları elde etmesi için gerekli tutum, anlayış ve uygulamaları geliştirme firsatlarının öğretmenler tarafından sağlanması beklenmektedir. En içteki dairede ise vatandaşlık eğitimi ile ilgili çeşitli terimlere ve konulara yer verilmektedir. Yine öğretmenlerden sosyal bilgiler, tarih ve coğrafya müfredatındaki vatandaşlık eğitimi ile kazanımları ve diğer derslerin müfredatları arasında bağlantı kurarken bu terimlere ve konulara odaklanmaları istenmektedir. Bu çerçevede her kavram ve konu, belirli bir ögeye bağlanmıştır. İç dairedeki kavramlar, birbirinden kesik noktalar ile ayrılmıştır. Bu kesik noktalar, bir kavramın birçok alana ait kavramlarla ilişkili olduğuna ve onlarla birlikte kullanılabileceğini göstermektedir (OMOE, 2018). 

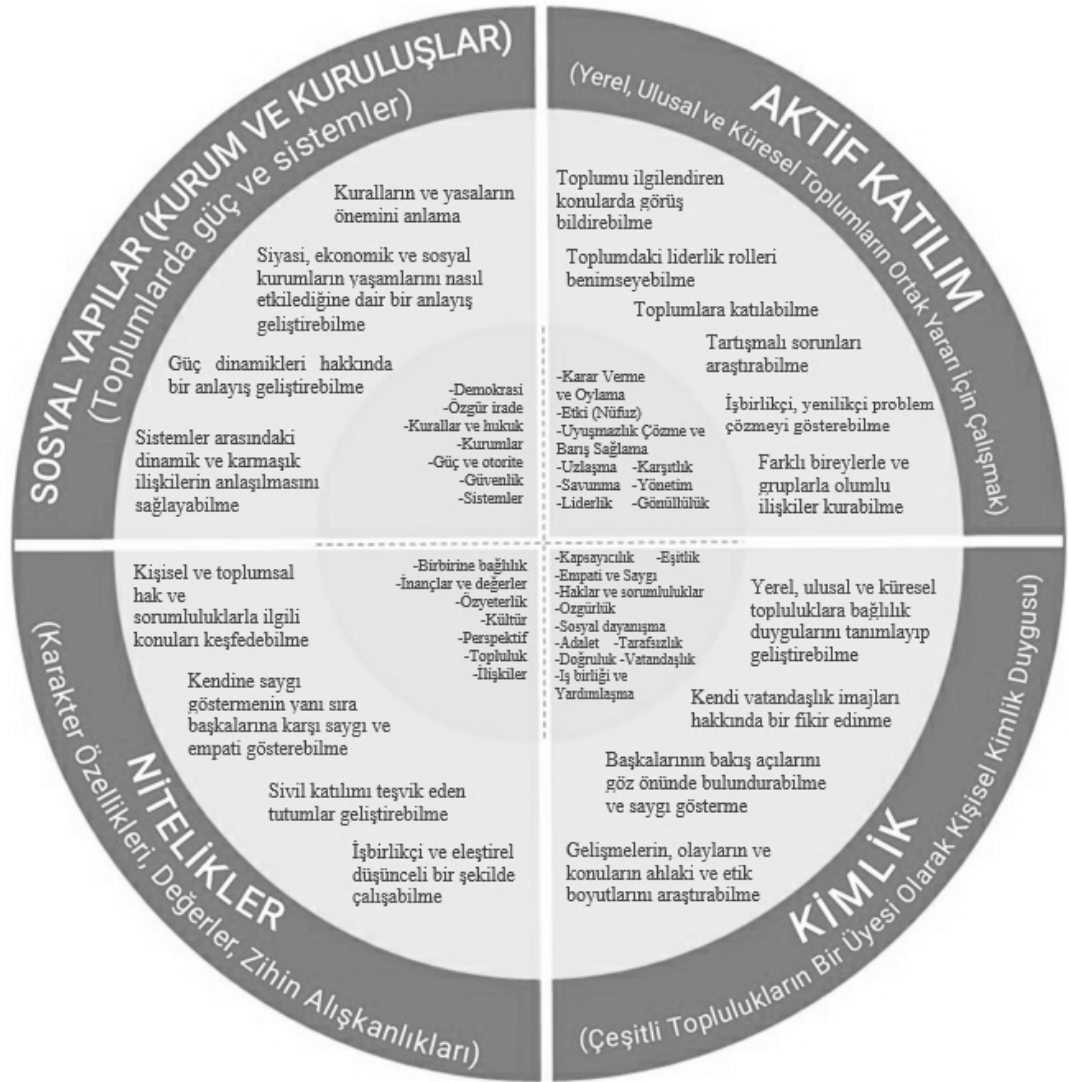

Şekil 1. Ontario Vatandaşlık Eğitimi Çerçevesi

Öte yandan Türkiye sosyal bilgiler öğretim programında, özel olarak vatandaşlık eğitiminin temel unsurları veya bileşenlerinin oluşturulmadığ görülmektedir. Programın genel yapısı; öğrenmeyi organize eden disiplinler arası bir yapıyı temsil eden öğrenme alanları, öğretim programının perspektifini oluşturan ilkeler toplamını ifade eden değerler, yetkinlikler ve becerilerden meydana gelen dört temel parçadan oluşmaktadır (MEB, 2018c). Bu genel yapı içerisinde vatandaşlık eğitimine dolaylı olarak çeşitli noktalarda atıflar yapılmıştır.

\section{Programlarda Vatandaşlık Eğitiminin Öğrenme Alanlarına (Te- malara) Göre Dağılımı}

Üçüncü araştırma sorusu kapsamında programlarda vatandaşlık eğitiminin öğrenme alanlarına (temalara) göre dağılımı incelenmiştir.

\section{Ontario Programının Temalarında Vatandaşlık Eğitimi}


Ontario programında vatandaşlık eğitimi kazanımları, 1-6. sınıflarda sosyal bilgiler dersi içerisinde "Miras ve Kimlik" ve "İnsanlar ve Çevreler" temalarında; 7-8. sinıflarda "Tarih" ve "Coğrafya" ders konuları içerisinde yer almıştır.

\section{Miras ve kimlik teması.}

$\mathrm{Bu}$ tema ile öğrencilere geçmiş ve şimdiki zaman arasındaki bağlant1ların anlaşılmasını sağlayacak konuları keşfetme fırsatı sunulmaktadır (OMOE, 2018). Bu kapsamda sömürgeciliğin etkilerini anlama, vatandaşlıkla ilgili hak ve sorumlulukları keşfetme (değişen rol ve sorumluluklar), Kanada'daki mirasın oluşmasındaki çeşitli katkıların kişisel, kültürel ve ulusal kimlikleri hakkında bir anlayış geliştirebilme gibi kimlik, kültür ve vatandaşlık ilişkisini ele alan konulara yer verilmiştir.

\section{Insanlar ve çevreler teması.}

$\mathrm{Bu}$ tema içerisinde öğrencilerden yerel, bölgesel, ulusal ve küresel topluluklar bağlamında coğrafi, sosyal, politik, ekonomik ve çevresel sorunları araştırmaları beklenmektedir. Bunun yanında vatandaşların ve çeşitli hükümet seviyelerinin sosyal ve çevresel sorumluluklarını anlamaları amaçlanmaktadır.

\section{Tarih dersinde vatandaşlık.}

$\mathrm{Bu}$ ders içerisinde öğrencilerin Kanada mirasını ve kimliğini, tarihi olayların içeriğini anlaması, Kanada' daki bazı gruplar, bireyler ve toplulukları tanımlaması, onların Kanada mirasına veya kimliğine katkılarını açıklaması ve tarihsel bağlamda Kanada toplumunun çeşitliliği ve karmaşıklığının gerekçelerini yorumlamaları beklenmektedir. Ayrıca öğrencilerin bilinçli ve sorumlu küresel vatandaşlar olarak rollerini yerine getirmelerine yardımc1 olmak için tarihten örnekler sunulmuştur.

\section{Coğrafya dersinde vatandaşlık.}

$\mathrm{Bu}$ derste öncelikle öğrencilere insan ve çevrenin birbirlerini nasıl etkilediğini analiz etme imkânı sunulmaktadır. Bunların yanında öğrencilere çevreye karşı sorumlu vatandaşlık becerilerini geliştirmelerine imkân verilerek, doğal kaynakların kullanımı ve sürdürülebilirliği konusunda bilinç kazanmaları amaçlanmaktadır. Ayrıca ekonomik gelişme ve yaşam kalitesi arasındaki ilişkiyi anlamaları beklenen öğrencilerin, toplumun refahı için çalışan çeşitli grupları ve örgütleri tanımalarına yönelik konulara da yer verilmiştir. 


\section{Türkiye Sosyal Bilgiler Programının Öğrenme Alanlarında Va- tandaşlık Eğitimi}

Yedi öğrenme alanı çerçevesinde disiplinler arası bir yaklaşımla yapılandırılan Türkiye sosyal bilgiler öğretim programında vatandaşlık eğitimi konuları, ağırlıklı olarak "Etkin Vatandaşlık" öğrenme alanında yer almaktadır. Bunun yanında programın diğer öğrenme alanlarında vatandaşlık eğitimine kısmen değinilmiştir. Öncelikle "Etkin Vatandaşlık" öğrenme alanı incelenmiş ve amaçlara ilişkin kazanımlar ile aşağıdaki Tablo 1'de sunulmuştur:

Tablo 1. Etkin Vatandaşlık Öğrenme Alanındaki İlgili Kazanımlar (MEB, 2018c)

\begin{tabular}{|c|c|}
\hline \multicolumn{2}{|c|}{ Amaç-Kazanım Eşleştirmeleri } \\
\hline Amaç & Öğrenciler, örgütlü bir devlet gücünün varlığını kavrarlar. \\
\hline Kazanım & $\begin{array}{l}\text { SB.4.6.4. "Ülkesinin bağımsızlığı ile bireysel özgürlüğü arasındaki ilişkiyi } \\
\text { açıklar." }\end{array}$ \\
\hline Amaç & Öğrenciler, düzenin nasıl sağlandığını anlarlar. \\
\hline Kazanım & SB.5.6.2. "Yaşadığı yerin yönetim birimlerinin temel görevlerini açıklar." \\
\hline Amaç & Öğrenciler, birey haklarının nasıl korunduğunu kavrarlar. \\
\hline Kazanım & $\begin{array}{l}\text { SB.6.6.5. "Türkiye Cumhuriyeti’nin etkin bir vatandaşı olarak hak ve sorumlu- } \\
\text { luklarının anayasal güvence altında olduğunu açıklar." }\end{array}$ \\
\hline Amaç & Öğrenciler, yönetimi etkileyecek demokratik yolları keşfederler. \\
\hline Kazanım & $\begin{array}{l}\text { SB.6.6.1. "Demokrasinin temel ilkeleri açısından farklı yönetim biçimlerini } \\
\text { karş1laştırır." }\end{array}$ \\
\hline
\end{tabular}

Tablo 1'de görüldüğü gibi, "Etkin Vatandaşlık” öğrenme alanı içerisinde; öğrencilere, örgütlü bir devlet yapısının varlığı kavratılarak düzenin nasıl sağlandığını anlamaları ve haklarının nasıl korunduğu ve bu haklar ile hangi demokratik yollara başvurabilecekleri kazanımlar yoluyla belirlenmiştir. Diğer yandan vatandaşlık eğitimi konuları yalnızca etkin vatandaşlık öğrenme alanında değil, diğer altı öğrenme alanındaki çeşitli kazanımlarda da yer almaktadır. İlgili öğrenme alanları öğrencilere; toplumdaki kimlikleri hakkında bir çıkarımda bulunmalarını (Birey ve Toplum), milli kültürüne ait ögeleri benimsemelerini (Kültür ve Miras), çevrelerine karşı sorumluluklarını anlamalarını (İnsanlar, Yerler ve Çevreler), bilimsel hayatta etiğin önemini kavramalarını (Bilim, Teknoloji ve Toplum), bilinçli bir tüketici olarak hak ve sorumluluklarını bilmelerini (Üretim, Dağıtım ve Tüketim) ve dünyadaki gelişmeleri takip ederek sorunlara çözüm üretebilmelerini sağlayacak yeterlikler (Küresel Bağlantılar) kazandırmayı amaçlamaktadır. 


\section{Programlarda Vatandaşlık Eğitimi Kapsamında Kazandırılmak İstenen Değerler}

Dördüncü araştırma sorusu kapsamında programlarda vatandaşl1k eğitimi ile öğrencilere kazandırılmak istenen değerler bu başlık altında incelenmiştir.

\section{Ontario Programındaki Vatandaşlık Değerleri}

Ontario öğretim programının genel yapısı incelendiğinde doğrudan “değerler” başlığı altında bir kısma yer verilmediği belirlenmiştir. Programda özel olarak sunulan vatandaşlık çerçevesinden hareketle aşağıdaki değerler belirlenmiştir:

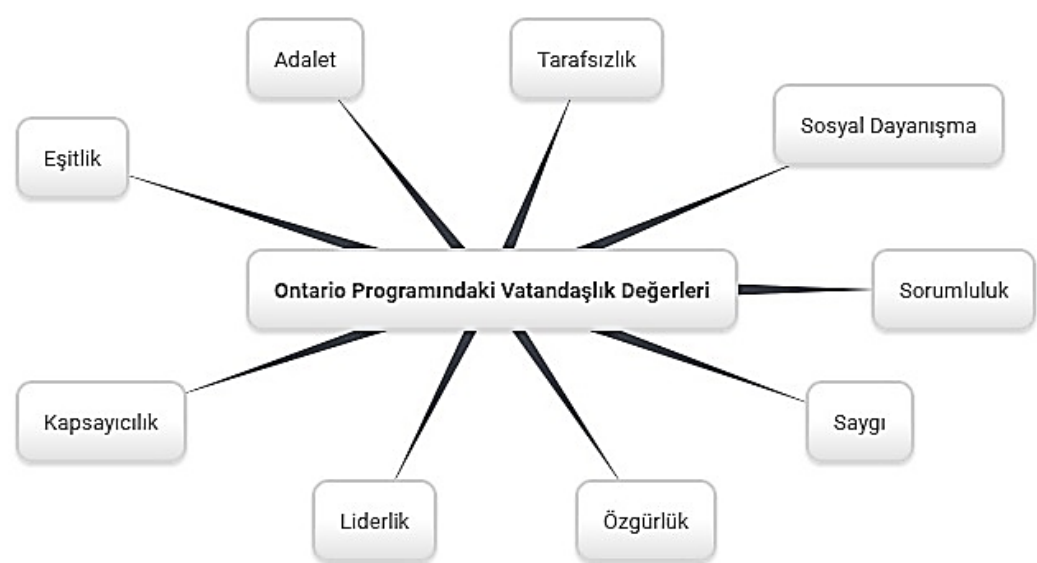

Şekil 2. Ontario Programında Vatandaşlık Değerleri

Şekil 2'de görüldüğü gibi, "Vatandaşlık Eğitimi Çerçevesi" kapsamında "eşitlik, adalet, tarafsızlık, sosyal dayanışma, sorumluluk, saygı, özgürlük, liderlik ve kapsayıcılık" gibi değerlere vurgu yapılmıştır. Daha önce Şekil 1'in ikinci dairesinde tanımlanan bilgi, beceri ve tutumların kazanılmasında, bu değerlerin önemli bir yeri olduğunu söylemek mümkündür.

\section{Türkiye Sosyal Bilgiler Programındaki Vatandaşlık Değerleri}

Türkiye programı temel değerleri benimsemiş bireyler yetiştirerek, yeni neslin değerlerini, alışkanlıklarını ve davranışlarını etkileyebilmeyi hedeflemektedir. $\mathrm{Bu}$ hedeften hareketle öğretim programında yer alan değerler, vatandaşlık eğitimi açısından incelenmiş ve vatandaşlık eğitimine ilişkin değerlerin "Etkin Vatandaşlık" öğrenme alanı içerisinde doğrudan verildiği tespit edilmiştir. Öğretim programı kapsamında belirlenen değerler aşağıdaki şekilde ifade edilmiştir: 


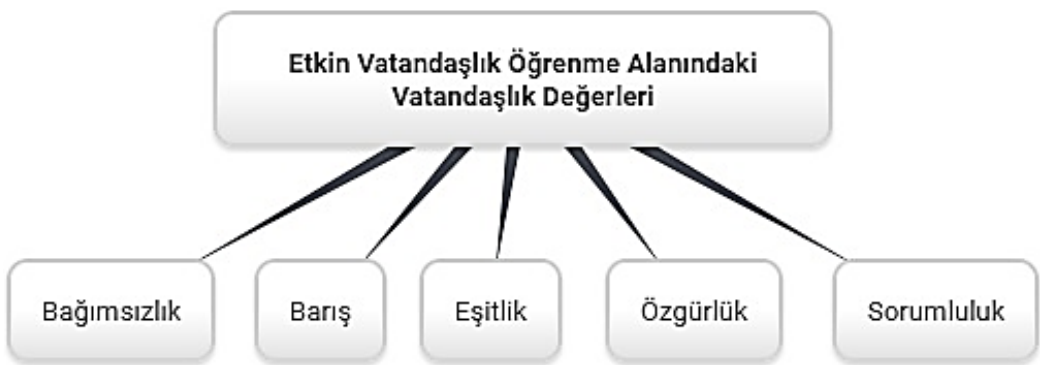

Şekil 3. Türkiye Programı Etkin Vatandaşlık Öğrenme Alanı Vatandaşlık Değerleri

Şekil 3’te görüldüğü gibi, "Etkin Vatandaşlık” öğrenme alanında doğrudan verilecek "sorumluluk, bağımsızlık, eşitlik, barış ve özgürlük" gibi değerlere vurgu yapılmaktadır. Bunun yanı sıra diğer öğrenme alanlarında vatandaşlık eğitimiyle ilgili tespit edilen kazanımlar ve değerlerin eşleştirmesi, aşağıdaki Tablo 2'de sırayla sunulmuştur:

Tablo 2. Diğer Öğrenme Alanlarında Kazandırılmak İstenen Vatandaşlık Değerleri ve Kazanım Örnekleri

\begin{tabular}{ll}
\hline Değerler & Kazanımlar \\
\hline Saygı & SB.4.1.5. "Diğer bireylerin farklı özelliklerini saygı ile karşılar.” \\
\hline $\begin{array}{l}\text { Dayanışma ve } \\
\text { Yardımseverlik }\end{array}$ & $\begin{array}{l}\text { SB.6.1.4. "Toplumsal birlikteliğin oluşmasında sosyal yardımlaşma ve } \\
\text { dayanışmayı destekleyici faaliyetlere katılır.” }\end{array}$ \\
\hline $\begin{array}{l}\text { Kültürel Mirasa } \\
\text { Duyarlılık }\end{array}$ & $\begin{array}{l}\text { SB.4.2.2. "Ailesi ve çevresindeki millî kültürü yansıtan ögeleri araştırarak } \\
\text { örnekler verir.” }\end{array}$ \\
\hline $\begin{array}{l}\text { Dürüstlük ve } \\
\text { Bilimsellik }\end{array}$ & SB.5.4.5. "Yaptığı çalışmalarda bilimsel etiğe uygun davranır.” \\
\hline Tasarruf & SB.4.5.5. "Çevresindeki kaynakları israf etmeden kullanır.” \\
\hline Vatanseverlik & $\begin{array}{l}\text { SB.6.5.2. "Kaynakların bilinçsizce tüketilmesinin canlı yaşamına etkilerini } \\
\text { analiz eder.” }\end{array}$ \\
\hline Çalışkanlık & $\begin{array}{l}\text { SB.7.5.5. Dünyadaki gelişmelere bağlı olarak ortaya çıan yeni meslekleri } \\
\text { dikkate alarak mesleki tercihlerine yönelik planlama yapar. }\end{array}$ \\
\hline
\end{tabular}

Tablo 2'den yola çıkılarak diğer öğrenme alanları içesindeki kazanımlar ile bireylere "saygı, dayanışma, yardımseverlik, kültürel mirasa duyarlılık, dürüstlük, bilimsellik, tasarruf, vatanseverlik ve çalışkanlık" değerlerinin kazandırılmak istendiği anlaşılmaktadır.

Şekil 3 ve Tablo 2'de görüldüğü gibi her iki öğretim programında kazandırılmak istenen yetkinlikler ile bireylere belli başlı değerlerin benimsetilmek istendiği tespit edilmiştir. Belirlenen bu değerlerden bazılarının ortak olduğu görülmüş ve ortak olan değerler aşağıdaki Şekil 4'te sunulmuştur: 


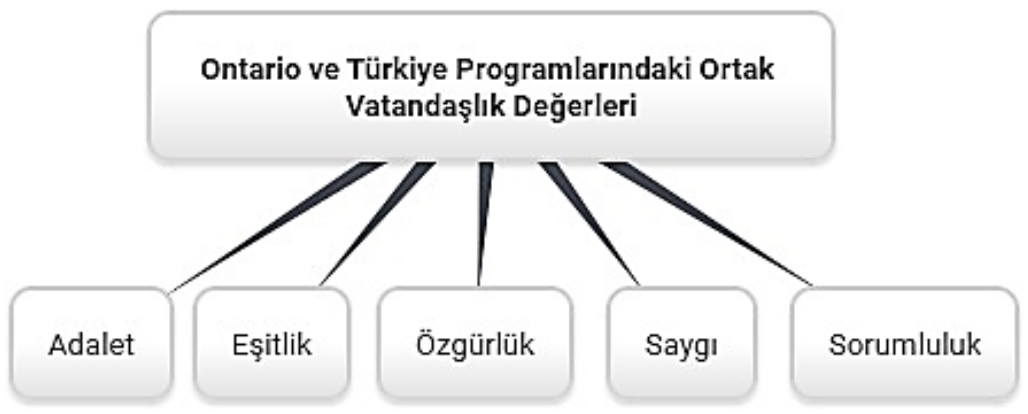

Şekil 4. Türkiye ve Ontario Programlarındaki Ortak Vatandaşlık Değerleri

Şekil 4'te görüldüğü gibi her iki öğretim programında da kazandırılmak istenen değerlerin "adalet, eşitlik, özgürlük, saygı ve sorumluluk" olduğu tespit edilmiştir. Bu durum, her iki programın, evrensel değerleri benimsediğini ve amaçlarına yansıttığını göstermektedir.

\section{Programlarda Vatandaşlık Eğitimi Kapsamında Kazandırılmak İstenen Beceriler}

Dördüncü araştırma sorusu kapsamında programlarda vatandaşlık eğitimi ile öğrencilere kazandırılmak istenen beceriler bu başlık altında incelenmiştir.

\section{Ontario Programındaki Vatandaşlık Becerileri}

Ontario öğretim programına genel yapı olarak bakıldığında kazand1rılmak istenen becerilerin doğrudan programda yer almadığı belirlenmiştir. Program içeriğinden ve programda özel olarak sunulan vatandaşlık çerçevesinden hareketle birtakım beceriler belirlenmiş ve aşağıda Şekil 5'te sunulmuştur.

Şekil 5 'te tespit edilen beceriler haricinde, program içeriğinden kazanımlar kapsamında vatandaşlık eğitimi ile ilişkili olan bazı beceriler belirlenmiştir. Öğrencilerden, farklı bölge ve dönemlerde yaşayan toplumların yaşamlarının kilit yönlerini karşılaştırabilmesi ve bu toplumlar ile bugünkü Kanada toplumları arasındaki bazı temel benzerlikler ve farklılıklar tanımlayabilmesi beklenmektedir. Böylece öğrencilerin "değişim ve süreklilik” becerilerinin geliştirilmesinin amaçlandığı tespit edilmiştir. Ayrıca bu toplumlardaki birey ve gruplar tarafindan gerçekleştirilen eylemleri analiz edip bugünkü eylemler ile karşılaştırarak, günümüz yaşamını daha iyi hale getirmeye çalışan öğrencilerin "zaman ve kronolojiyi algılama" becerisinin geliştirilmek istendiği görülmüştür. 


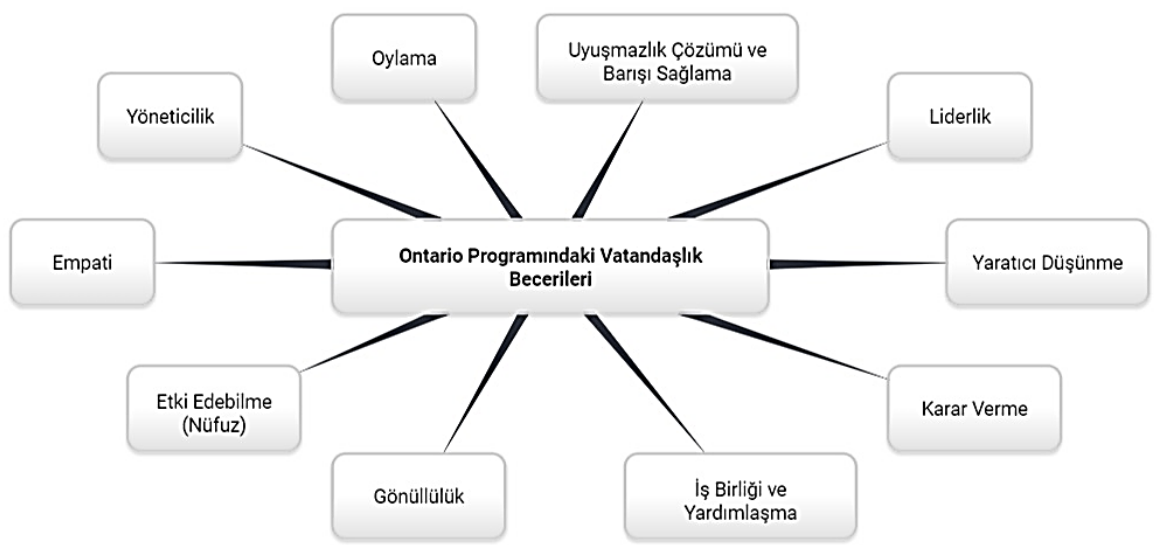

Şekil 5. Ontario Programındaki Vatandaşlık Becerileri ${ }^{2}$

Bunların yanı sıra öğrencilerden, yerli toplumlarda dâhil olmak üzere toplumsal meselelerin çözümünden sorumlu devlet düzeylerinin ve toplumdaki farklı bakış açılarının zayıf ve güçlü yönlerini belirlemeleri hedeflenmektedir. Böylece toplumsal sorunlar hakkında bir değerlendirme ve sonuca ulaşmaya çalışan öğrencilerin "eleştirel düşünme becerisi”ni geliştirilmesinden söz etmek mümkündür.

\section{Türkiye Sosyal Bilgiler Programındaki Vatandaşlık Becerileri}

Türkiye sosyal bilgiler programı TYÇ ile bütünleşmiş bilgi, beceri ve davranışlara sahip bireyler yetiştirmeyi amaçlamaktadır. Bu yetkinliklerden bir tanesi doğrudan vatandaşlık eğitimi ile ilgilidir. Sosyal ve vatandaşlıkla ilgili yetkinlikler bireyleri; toplumsal, siyasal kavram ve yapılara ilişkin bilgiye, demokratik ve aktif katılım kararlılığına dayalı olarak medeni hayata tam katılımları için donatmaktadır (MEB, 2018c). TYÇ doğrultusunda belirlenen beceriler vatandaşlık eğitimi açısından incelendiğinde "Etkin Vatandaşlık" öğrenme alanı içerisinde doğrudan verilen beceriler aşağıdaki Şekil 6'da belirtilmiştir:

\footnotetext{
2 "Gönüllülük", Ontario Vatandaşlık Çerçevesinde "Volunteering" olarak geçen kelime takım içerisinde çalışabilme becerisini ifade etmektedir. Karar verme becerisi, Ontario Vatandaşlık Çerçevesinde daha çok siyasi olarak karar vermeyi vurgulamaktadır. Ancak programın genelinde ve diğer konuların ele alınışında sorunların çözümünde karar verme becerilerinin problem çözme becerisiyle birlikte kullanıldığı görülmüştür. İş birliği ve yardımlaşma becerisi, Ontario Vatandaşlık Çerçevesinde "Collaboration", ortak amaç için birlikte çalışabilme becerisini, "Cooperation" ise ayrı bir amaç için başka birinin hedefine ulaşmasına yardımcı olmak şeklinde ifade edilmiştir.
} 


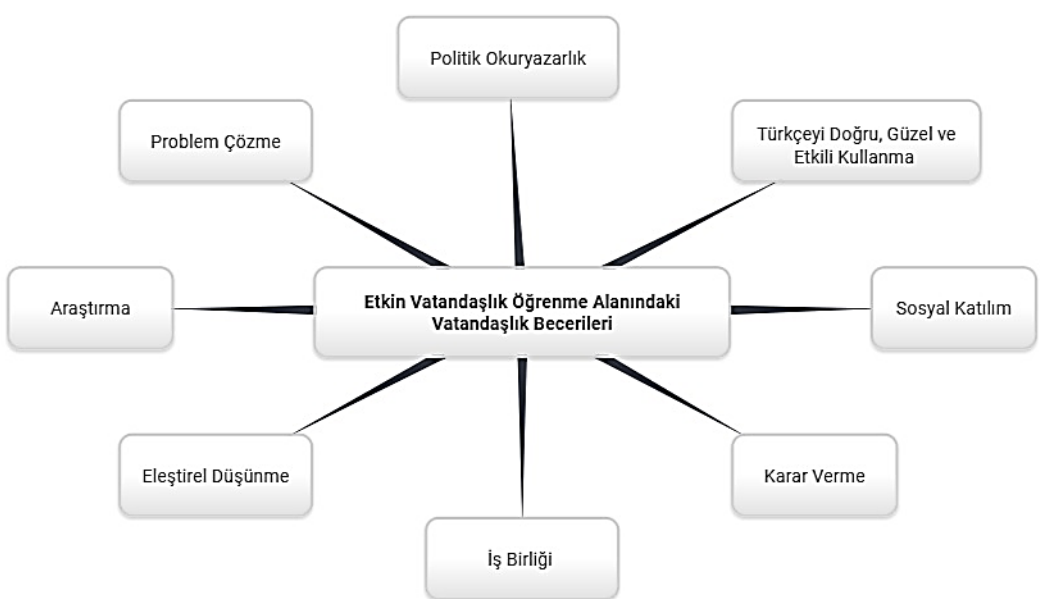

Şekil 6. Türkiye Programı Etkin Vatandaşlık Öğrenme Alanındaki Vatandaşlık Becerileri

Şekil 6'da görüldüğü gibi, "Etkin Vatandaşlık" öğrenme alanı ile vatandaşlık eğitimi kapsamında öğrencilere kazandırılmak istenen sekiz beceri tespit edilmiştir. Böylece araştıran, olaylara eleştirel yaklaşıp sorunlara çözüm getirebilen, iş birliği içerisinde sosyal katılım sağlayan bir vatandaş niteliklerine vurgu yapıldığını söylemek mümkündür. Ayrıca diğer öğrenme alanlarında vatandaşlık eğitimi ilgili tespit edilen kazanımlar ve becerilerin eşleştirmesi, aşağıdaki Tablo 3'te sırayla sunulmuştur.

Tablo 3. Diğer Öğrenme Alanlarında Kazandırılmak İstenen Vatandaşlık Becerileri

\begin{tabular}{ll}
\hline Beceriler & Kazanımlar \\
\hline Empati kurma & $\begin{array}{l}\text { SB.4.1.4. "Kendisini farklı özelliklere sahip diğer bireylerin yerine } \\
\text { koyar." }\end{array}$ \\
\hline $\begin{array}{l}\text { Zaman ve kronolojiyi } \\
\text { algılama }\end{array}$ & $\begin{array}{l}\text { SB.6.1.2. "Sosyal, kültürel ve tarihî bağların toplumsal birlikteliğin } \\
\text { oluşmasındaki yerini ve rolünü analiz eder.” }\end{array}$ \\
\hline Çevre okuryazarlığı & $\begin{array}{l}\text { SB.5.3.4. "Yaşadığı çevredeki afetlerin ve çevre sorunlarının } \\
\text { oluşum nedenlerini sorgular.” }\end{array}$ \\
\hline Dijital okuryazarlık & $\begin{array}{l}\text { SB.5.4.2. "Sanal ortamda ulaştığı bilgilerin doğruluk ve güvenilir- } \\
\text { liğini sorgular." }\end{array}$ \\
\hline Finansal okuryazarlık & $\begin{array}{l}\text { SB.4.5.3. "Sorumluluk sahibi bir birey olarak bilinçli tüketici } \\
\text { davranışları sergiler.” }\end{array}$ \\
\hline
\end{tabular}

Tablo 3'te, diğer öğrenme alanlarında, çevre sorunlarıla ilgilenebilecek, sanal ortamda güvenliğe dikkat edebilecek, diğer bireyler ile empati kurabilecek, bilinçli tüketici sorumluluklarına sahip olabilecek, geçmiş ve gelecek arasındaki bağlantıyı ve değişimi algılayabilecek becerilere sahip 
bireylerin yetiştirilmesinin amaçlandığı görülmektedir.

Şekil 6 ve Tablo 3'ten hareketle her iki öğretim programında bireylere kazandırılmak istenen bazı becerilerin ortak olduğu belirlenmiş ve aşağıdaki Şekil 7'de verilmiştir:

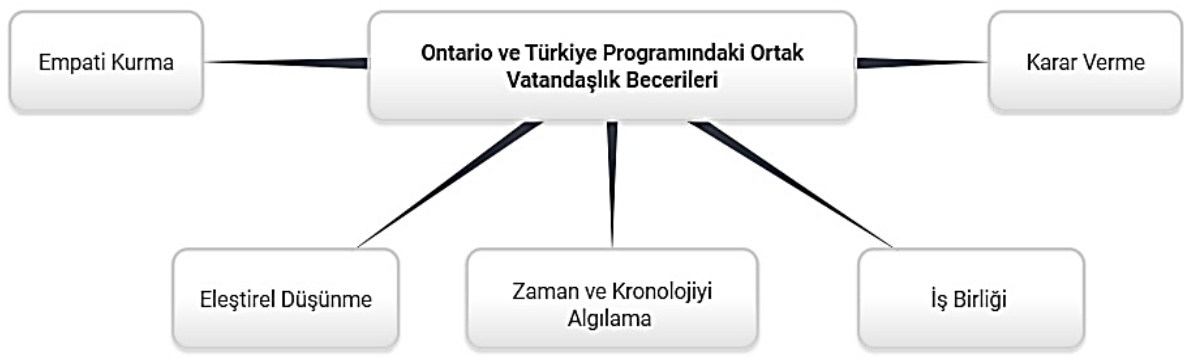

Şekil 7. Türkiye ve Ontario Programındaki Ortak Vatandaşlık Becerileri

Şekil 7'deki beceriler, her iki öğretim programının; geçmiş ve gelecek arasındaki bağlantıyı anlayabilme, olaylara eleştirel yaklaşarak karar verebilme ve bu olayların çözümünde iş birliği içerisinde hareket edebilme ve aynı zamanda empati kurabilmeye önem verdiğini göstermektedir.

\section{Programlarda Vurgulanan Vatandaşlık Tipleri}

Beşinci araştırma sorusu kapsamında programlar ile yetiştirilmek istenen vatandaş tipleri bu başlık altında incelenmiştir.

\section{Ontario programında vurgulanan vatandaşlı tipleri.}

Ontario programı, vatandaşlık eğitimi çerçevesi kapsamında incelenmiş ve bazı vatandaşlık tipleri belirlenmiştir. Belirlenen vatandaşlık tipleri ve ilişkili olduğu kazanımlar, aşağıdaki Tablo 4'te sunulmuştur.

Tablo 4'te görüleceği gibi Ontario programında kazanımlar doğrultusunda, toplumda sahip olduğu sorumlulukları bilen, geleneklerine sahip çıkan, çevre sorunlarını ele alan, sahip olduğu temel hakları bilen, ülkesindeki çeşitli toplumlardaki sorunlara çözüm üreten ve bunu küresel boyuta taşıyabilen vatandaşlık tiplerine vurgu yapıldığ 1 tespit edilmiştir. 
Tablo 4. Vatandaş Tipleri

\begin{tabular}{ll}
\hline $\begin{array}{l}\text { Vatandaş } \\
\text { Tipi }\end{array}$ & Kazanımlar \\
\hline $\begin{array}{l}\text { Sorumlu } \\
\text { Vatandaş }\end{array}$ & $\begin{array}{l}\text { 1.B3.7. "Hükümetin sorumlu olduğu topluluktaki hizmetlerin bazılarını ve } \\
\text { topluluktaki kişilerin bu hizmetlerle ilgili temel sorumluluklarını tanımlayın." }\end{array}$ \\
\hline $\begin{array}{l}\text { Yerel } \\
\text { Vatandaş }\end{array}$ & $\begin{array}{l}\text { 2.A1. Farklı gruplar arasında ve farklı zamanlarda bazı önemli gelenekleri ve } \\
\text { kutlamaları karşılaştırınız ve bu gelenek ya da kutlamalardaki değişikliklerin } \\
\text { nedenlerini tanımlayınız. }\end{array}$ \\
\hline $\begin{array}{l}\text { Ekolojik } \\
\text { Vatandaş }\end{array}$ & $\begin{array}{l}\text { 5.B1.3. "Yerel, bölgesel ve ulusal öneme sahip bir çevre sorununu ele almak } \\
\text { için bir eylem planı oluşturun." }\end{array}$ \\
\hline $\begin{array}{l}\text { Ulusal } \\
\text { Vatandaş }\end{array}$ & $\begin{array}{l}\text { 5.B3.1. "Kanada'da vatandaşlıkla ilgili temel hak ve sorumlulukları tanımla- } \\
\text { yın." }\end{array}$ \\
\hline $\begin{array}{l}\text { Iyi } \\
\text { Vatandaş }\end{array}$ & $\begin{array}{l}\text { 5.B3.9. "Vatandaşların sosyal ve çevresel meseleleri ele almak için harekete } \\
\text { geçebilecekleri bazı yolları tanımlayın." }\end{array}$ \\
\hline $\begin{array}{l}\text { Aktif ve } \\
\text { Katılımcı } \\
\text { Vatandaş }\end{array}$ & $\begin{array}{l}\text { 5.B1. "İlk ulus, Métis ve Inuit hükümetlerini içeren Kanada'daki hükümetlerin } \\
\text { bazı önemli konulara verdiği yanıtları değerlendirin ve hükümetlerin ve va- } \\
\text { tandaşların sosyal ve çevresel sorunlarını ele alacak eylem planları geliştirin." }\end{array}$ \\
\hline Küresel & $\begin{array}{l}\text { 6.B1. "Uluslararası iş birliğinin küresel meseleleri ele almadaki önemini } \\
\text { açılayın ve seçilen eylemlerin Kanada ve Kanada vatandaşlarının uluslararası } \\
\text { arenadaki etkinliğini değerlendirin.” }\end{array}$ \\
\hline
\end{tabular}

\section{Türkiye sosyal bilgiler programında vurgulanan vatandaşlık tipleri.}

Ontario programından sonra Türkiye programının, öğrenme alanları, değerler ve becerileri vatandaşlık eğitimi kapsamında incelenmiş, bazı vatandaşlık tipleri belirlenmiş ve kazanımlar ile eşleştirilerek aşağıdaki Tablo 5 'te sunulmuştur.

Tablo 5'te görüleceği gibi, Türkiye sosyal bilgiler programında, aile ve okul yaşamındaki tutumlarında sorumlu olan "bireysel sorumlu vatandaş"; sanal ortamdaki davranışları ile "dijital vatandaş"; toplumsal hayatta etkin olan "katılımcı vatandaş"; çevresine duyarlı olan "ekolojik vatandaş"; ülkesine katkı sağlayacak tutumları gerçekleştiren "sorumlu vatandaş"; toplumsal dayanışmayı destekleyen "iyi vatandaş"; Türkiye Cumhuriyeti'nin etkin bir vatandaşı olarak ülkenin gelişimini ve bağımsızlı̆̆ının önemini anlayan "ulusal vatandaş" ve dünya sorunlarına çözüm üreten "küresel vatandaş" tiplerine vurgu yapıldığı tespit edilmiştir.

Tablo 4 ve 5'ten yola çıkarak her iki öğretim programının da "aktif ve katılımcı, sorumlu, iyi, ekolojik, ulusal ve küresel" düzeyde vatandaşlık tiplerine vurgu yaptığı belirlenmiştir. Bunun yanı sıra Türkiye sosyal bilgiler programında "Ulusal/ Türk Vatandaşlığı”na, Ontario programında ise birçok 
etnik grubu içinde barındırması sebebiyle "Küresel Vatandaşlık"a daha fazla değinildiği görülmüştür.

Tablo 5. Vatandaşlık Tipleri

\begin{tabular}{|c|c|}
\hline Vatandaş Tipi & Kazanımlar \\
\hline $\begin{array}{l}\text { Bireysel Olarak } \\
\text { Sorumlu Vatandaş }\end{array}$ & $\begin{array}{l}\text { SB.4.6.2. "Aile ve okul yaşamındaki söz ve eylemlerinin sorumlulu- } \\
\text { gunu alır." }\end{array}$ \\
\hline \multirow[t]{3}{*}{$\begin{array}{l}\text { Ulusal Vatandaş } \\
\text { /Türk Vatandaşliğ1 }\end{array}$} & $\begin{array}{l}\text { SB.4.6.4. "Ülkesinin bağımsızlığı ile bireysel özgürlüğü arasındaki } \\
\text { ilişkiyi açıklar." }\end{array}$ \\
\hline & $\begin{array}{l}\text { SB.5.1.1. "Sosyal Bilgiler dersinin, Türkiye Cumhuriyeti'nin etkin bir } \\
\text { vatandaşı olarak kendi gelişimine katkısını fark eder." }\end{array}$ \\
\hline & $\begin{array}{l}\text { SB.5.6.4."Millî egemenlik ve bağımsızlık sembollerimizden Bayrağı- } \\
\text { mıza ve İstiklâl Marşına değer verir." }\end{array}$ \\
\hline Dijital Vatandaş & $\begin{array}{l}\text { SB.5.4.2. "Sanal ortamda ulaştı̆̆ bilgilerin doğruluk ve güvenilirliğini } \\
\text { sorgular." }\end{array}$ \\
\hline $\begin{array}{l}\text { Aktif ve Katılımcı } \\
\text { Vatandaş }\end{array}$ & $\begin{array}{l}\text { SB.5.6.1. "Bireysel ve toplumsal ihtiyaçlar ile bu ihtiyaçların karş1- } \\
\text { lanması için hizmet veren kurumları ilişkilendirir." }\end{array}$ \\
\hline İyi Vatandaş & $\begin{array}{l}\text { SB.6.1.4. "Toplumsal birlikteliğin oluşmasında sosyal yardımlaşma ve } \\
\text { dayanışmayı destekleyici faaliyetlere katılır." }\end{array}$ \\
\hline Ekolojik Vatandaş & $\begin{array}{l}\text { SB.6.5.2. "Kaynakların bilinçsizce tüketilmesinin canlı yaşamına } \\
\text { etkilerini analiz eder." }\end{array}$ \\
\hline Sorumlu Vatandaş & $\begin{array}{l}\text { SB.6.5.4. "Vatandaşlık sorumluluğu ve ülke ekonomisine katkıs1 } \\
\text { açısından vergi vermenin gereğini ve önemini savunur." }\end{array}$ \\
\hline Küresel Vatandaş & $\begin{array}{l}\text { SB.7.7.4. "Arkadaşlarıyla birlikte küresel sorunların çözümüne yönelik } \\
\text { fikir önerileri geliştirir." }\end{array}$ \\
\hline
\end{tabular}

\section{Sonuç ve Tartışma}

$\mathrm{Bu}$ çalışmada Kanada (Ontario) ve Türkiye sosyal bilgiler öğretim programları vatandaşlık eğitimi açısından karşılaştırılmış ve değerlendirilmiştir. Bu kapsamda birinci araştırma sorusunda, programların vatandaşlık eğitimi amaçları incelenmiştir. Öncelikle Ontario programında vatandaşlık eğitimine yönelik özel bir vatandaşlık çerçevesinin hazırlandığ 1 ve vatandaşlık eğitiminin amacının bu çerçeveye bağlı olarak belirlendiği tespit edilmiştir. Türkiye sosyal bilgiler programında ise herhangi bir vatandaşlık çerçevesinin sunulmamasına rağmen vatandaşlık eğitiminin amacının sosyal bilgiler dersinin özel amaçlarında açıklandığı saptanmıştır. Bu farklılıklara karşın, her iki öğretim programının da demokratik, aktif ve etkili vatandaşlar yetiştirmeyi amaçladığını söylemek mümkündür. Daha önce Ontario ve Türkiye sosyal bilgiler programlarını amaçlar bağlamında karşılaştıran Öztürk ve Öztürk-Zayimoğlu (2013), her iki programın da etkili vatandaş yetiştirme üzerine odaklandığını ortaya koymuştur. Bunların dışında en önemli farklılık, 
Ontario programında yerel, ulusal ve küresel boyutta bir vatandaşlık vurgulanırken, Türkiye sosyal bilgiler programında daha çok Türkiye Cumhuriyeti vatandaşlığı ön plana çıkarılmıştır. Yine Öztürk ve Zayimoğlu-Öztürk (2013), bu durumu Türkiye programının milli menfaatleri merkeze alan bir yapıda olmasıyla açıklamıştır.

İkinci araştırma sorusu bağlamında programlarda yer alan vatandaşlık eğitimi bileşenleri (unsurları) incelenmiştir. Öncelikle Ontario öğretim programı içerisinde özel olarak sunulan vatandaşlık eğitimi çerçevesinin "aktif katılım, kimlik, nitelikler ve sosyal yapılar" olmak üzere dört temel unsurdan oluştuğu görülmüştür. Buna karşın Türkiye sosyal bilgiler programında özel bir vatandaşl1k eğitimi planına yer verilmemiş, vatandaşlık eğitimi konuları değerler, yetkinlikler, beceriler ve öğrenme alanları içerisinde yer bulmuştur.

Üçüncü araştırma sorusu kapsamında programlarda vatandaşlık eğitiminin öğrenme alanları ve temaları içerisinde nasıl bir dağılım gösterdiği incelenmiştir. İnceleme sonunda, Türkiye sosyal bilgiler programındaki etkin vatandaşlık öğrenme alanının, Ontario vatandaşlık çerçevesinde yer alan "aktif katılım ve sosyal yapılar" unsurlarındaki; birey ve toplum öğrenme alanının ise "kimlik ve nitelik" unsurları içerisindeki bilgi ve beceri geliştirme yollarıyla örtüştüğü görülmektedir.

Dördüncü araştırma sorusu kapsamında, programlarda vatandaşlık eğitiminde kazandırılmak istenen değerler ve beceriler incelenmiştir. Öncelikle her iki programın da "eşitlik, adalet, saygı, özgürlük ve sorumluluk" değerlerine sahip bireyler yetiştirmeyi hedeflediği belirlenmiştir. Ontario programının Türkiye sosyal bilgiler programından değerler açısından içerdiği en büyük farklılık, "kapsayıcılık" değerine yaptığı vurgudur. İlgili programda, öğrencileri çeşitliliği anlamaya teşvik etmek, sosyal bilgiler, tarih ve coğrafya programının odak noktalarından biri olmuştur (OMOE, 2018). Bunun yanında beceriler açısından bakıldığında, her iki programın da "empati kurma, eleştirel düşünme, karar verme, zaman ve kronolojiyi algılama ve iş birliği” becerilerine sahip bireyler yetiştirmeyi hedeflediği sonucuna ulaşılmıştır.

Araştırmanın son sorusuna yönelik olarak yapılan inceleme ile programlarda vurgulanan vatandaşlik tipleri belirlenmiştir. İlk olarak her iki programın da vatandaşlık eğitimi ile aktif ve katılımcı vatandaşlar yetiştirmeyi amaçladığ1 görülmektedir. Aktif ve katılımcı bir vatandaş; topluluk örgütlerinin aktif bir üyesi olarak, toplumdaki sosyal sorunları çözüp toplumu 
iyileştirmeye ve çevreyi temiz tutmaya çalışır. Bunun yanında ekonomik kalkınmayı teşvik eder ve devlet kurumlarının işleyişi ve sistemi hakkında fikir sahibi olur (Westheimer ve Kahne, 2004).

Bilindiği gibi ülkeler, belirlemiş oldukları eğitim sistemleri ile farklılık gösterseler de belki de en önemli ortak amaçları topluma iyi vatandaşlar ve iyi insanlar kazandırmaktır (Yavuz, Duman ve Karakaya, 2016). Bu açıdan bakıldığında ilgili programlarda bireylerin aktif ve katılımcı vatandaşlar olmasının yanında 'iyi vatandaş' olarak yetiştirilmeleri de vurgulanmaktadır. Alanyazında ifade edildiği gibi 'iyi vatandaş', yasalara uyan, topluma etkin şekilde katılabilen, başkalarına yardımda bulunan, erdem ve ahlak sahibi, saygılı ve vatansever bir bireydir (Dere, Kızılay ve Alkaya, 2017). Bu yönüyle her iki program da etkin ve katılımcı vatandaşların aynı zamanda toplumsal sorumluklara sahip olması istemektedir.

Öte yandan 'iyi vatandaş'ın niteliklerine sahip olan bireylerden aynı zamanda sorumlu bir vatandaş olması beklenmektedir. Sorumlu bir vatandaş, toplumsal sorunlara çözüm bulmada sorumluluk üstlenen, ailesi ve içinde bulunduğu topluma karşı yükümlülüklerini göz önünde bulundurarak kararlar alan bir birey olarak tanımlanmaktadır (Spellings, 2005). Ailesi ve topluma karş1 sorumluluklarını yerine getiren vatandaşın çevreye karşı da sorumlu olması beklenebilir. Ekolojik (çevresel) vatandaşılık olarak ifade edilen bu vatandaş tipine her iki programda da vurgu yapılmaktadır. Ekolojik ya da çevresel vatandaş; çevreyi kamunun malı olarak gören ve ortak yarar için korunması gerektiğini savunan kişidir. Çevresel vatandaş, aynı zamanda sürdürülebilir toplum için geri dönüşüm, yeniden kullanma, koruma gibi faaliyetlerde bulunur (Dobson, 2007). Tüm yönleriyle değerlendirildiğinde, her iki programın da aktif, katılımcı, iyi ve ailesine, topluma ve çevreye karşı duyarlı ve sorumlu vatandaşlar yetiştirmek istediği görülmektedir.

Birçok vatandaş tipine vurgu yapan programlar, aynı zamanda öğrencilerin hem ulusal hem de küresel vatandaş özelliklerine sahip olmaları gerektiğini belirtmektedir. Ancak programların ulusal ve küresel vatandaşl1k anlayışları bazı yönlerden farklılaşmaktadır. Ontario programında, yerel, ulusal ve küresel toplum düzeylerinde vatandaşlık sorumluluklarına bir arada yer verildiği görülmektedir. Bu programda öğrencilerin bir vatandaş olarak, yerel, ulusal ve küresel ölçekte toplumların ve milletlerin gelenekleri, kültürleri, inançları ve bakış açıları hakkında bilgi sahibi olmaları ve birbirlerine saygı duymaları amaçlanmaktadır (OMOE, 2007). Buna karşın Türkiye sos- 
yal bilgiler programında, yerel küresel ölçekteki konulara yer verilmesine rağmen daha çok ulusal vatandaşlık vurgusu yapılmıştır. Massey (2014), vatandaşlık kavramının daha çok ulus-devletle ilişkilendirilmesine rağmen, küreselleşme ve Kanada gibi küresel göçlerin odağında olan çok kültürlü ülkelerde küresel vatandaşlık eğitimine ağırlık verilmesinin gerekliliğini vurgulamıştır. Ancak bu noktadaki küresel vatandaşlık modelinde, bireyin küresel boyutta bilgi, beceri ve anlayışını yaşam tarzına yansıtabilmek olduğunu vurgulamak yerinde olacaktır. Bu noktada küresel bir vatandaştan, milli değerlerini reddetmeyerek evrensel değerler ve farkl1lıklara saygı duyması (Kan, 2009) beklenmektedir. Bu bağlamda, Türkiye sosyal bilgiler öğretim programında, küresel bağlantılar öğrenme alanı ile bireylerin dünyayı ilgilendiren konularda duyarlılık gösteren, gelişen dünyanın gündemini takip eden, karşılaştığı sorunlara çözüm üretebilen etkin ve sorumlu Türk vatandaşları yetiştirmek amaçlandığı ifade edilmiştir (MEB, 2018c). Bu durum, Türkiye programının küresel vatandaşlı̆̆ 1 reddetmediğini, bilakis içerdiğini göstermektedir. Türkiye sosyal bilgiler programından farklı olarak, bir göçmenler ülkesi olan Kanada programında küresel vatandaşlık vurgusu daha fazladır. Massey (2014) tarafından vurgulandığı gibi, çeşitli inançları ve milletleri barındıran Kanada için kapsayıcılık ve küresel yaklaşım, bir ihtiyaçtır.

Ulusal ve küresel vatandaşlik özellikleriyle Ontario programından farkl11ık gösteren Türkiye sosyal bilgiler programında daha çok "bireysel sorumlu vatandaş"ın niteliklerine vurgu yapıldığg görülmüştür. Bu kapsamda öğrencilerden; aile ve okul hayatındaki söz ve eylemlerinin sorumluluğunu alması (MEB, 2018c), toplumsal düzenin devamı için çöp toplayarak, kan vererek, geri dönüşüme katkı sağlayarak ve yasalara uyarak bireysel olarak sorumlu vatandaş olmaları beklenmektedir. Bunun yanında bireysel olarak sorumlu vatandaşa vurgu yapan ilgili program; dürüstlük, öz disiplin ve sık1 çalışma gibi karakter ve kişisel nitelikleri de geliştirmeyi amaçlamaktadır (Westheimer ve Kahne, 2004).

Öte yandan teknoloji kullanımına, sanal ortamdaki güvenlik kurallarına ve bilimsel etiğe (MEB, 2018c) vurgu yapan Türkiye programı ve dijital temsil, dijital kaynak ve araç kullanımı konulara değinen Kanada programı, dijital vatandaşlar yetiştirmeyi amaçlamaktadır. Bilindiği gibi, çeşitli teknolojik araçları sıkı bir şekilde kullanarak vatandaşlık görevlerini yerine getirme ve topluma çevrimiçi olarak katılma yeteneğine sahip kişiler, dijital vatandaş 
olarak adlandırılmaktadır (Mossberger, Tolbert ve McNeal, 2008). Bu nitelikler göz önünde bulundurulduğunda, her iki programının da dijital ortamlarda güvenli, sorumlu ve etik kurallara dikkat eden vatandaşlar yetiştirmek istediğini söylemek mümkündür.

\section{Öneriler}

Yapılan araştırmanın sonuçlarından yola çıkarak Türkiye Sosyal Bilgiler Öğretim Programı için şu önerilerde bulunulabilir:

- Öğretim programı içerisinde kullanılan kavramları açıkça tanımlayacak bir sözlüğe yer verilmesi, programı kullanan tüm öğretim paydaşları için yararlı olacaktır.

- Sosyal bilgiler dersinin en önemli amaçlarından biri olan etkin vatandaşlığın programda daha açık bir şekilde ele alınması ve Kanada'da olduğu gibi vatandaşlık çerçevesinin oluşturulması, vatandaşlık eğitimini daha anlaşılır hale getirecektir.

- Dünya ile entegre vatandaşlar yetiştirmek için küresel vatandaşl1k konularına ve dünyadaki güncel sorunlara daha fazla ağırlık verilmelidir. Bu konular, yerel, milli ve küresel ölçekte, yakından uzağa ilkesiyle uyumlu bir şekilde sunulmalıdır.

\section{Kaynakça}

Alkın, S. (2007). Ingiltere ve Türkiye'de ilköğretim programlarındaki vatandaşlık eğitiminin karşılaştırılması. Yayımlanmamış doktora tezi, Ankara Üniversitesi Eğitim Bilimleri Enstitüsü.

Arslan, M. (2007). Eğitimde yapılandırmacı yaklaşımlar. Ankara Üniversitesi Ĕgitim Bilimleri Fakültesi Dergisi, 40(1), 41-61.

Bektaş, Ö. ve Zabun, E. (2019). Vatandaşlık eğitiminde değerler karşılaştırması: Türkiye ve Fransa. Değerler Ĕgitimi Dergisi, 17, 247-289.

Bursa, S. ve Çengelci-Köse, T. (2017). Türkiye ve Kanada sosyal bilgiler öğretim programlarının değerler eğitimi bakımından karşılaş̧ırılması. Anadolu Journal of Educational Sciences International, 7(2), 338-372.

Canadian Multiculturalism Act (1988). https://laws-lois.justice.gc.ca/pdf/C-18.7.pdf

Delibaş, H. (2007). Türkiye, İngiltere, Almanya ve Finlandiya biyoloji ögretmeni yetiştirme programlarının karşılaştırılması. Yayımlanmamış yüksek lisans tezi, Ankara Üniversitesi Eğitim Bilimleri Enstitüsü.

Dere, İ., Kızılay, N. ve Alkaya, S. (2017). 'İyi vatandaş' kavramı, ailede ve okulda 'iyi vatandaşlık' eğitimi hakkında velilerin görüşleri ve algıları. International Journal of Eurasia Social Sciences, 8(30), 1974-1993.

Dobson, A. (2007). Environmental citizenship: Towards sustainable development. Sustainable Development, 15(5), 276-285.

Erdoğan, İ. (2003). Karşılaştırmalı eğitim: Türk eğitim bilimleri çalışmaları içinde 
önemsenmesi gereken bir alan. Türk Eğitim Bilimleri Dergisi, 1(3), 265-282.

Ersoy, A. F. (2007). Sosyal bilgiler dersinde ögretmenlerin etkili vatandaşlık ĕgitimi uygulamalarına ilişkin görüşleri. Yayımlanmamış doktora tezi, Anadolu Üniversitesi Eğitim Bilimleri Enstitüsü.

Erzurumlu, S. (2008). Çokkültürcülük politikası ve Kanada'da çokkültürcülük. Yayımlanmamış yüksek lisans tezi, Süleyman Demirel Üniversitesi Sosyal Bilimler Enstitüsü.

Hébert, Y. (2009). Responsibility and citizenship education: Shifting meanings, policy and curricula. Citizenship Teaching and Learning, 5(2), 4-15.

Heinhorst, T. (2008). Promoting citizenship. Stone, R., (Ed.), Best practices for teaching reading içinde (89-92). California: Corwin Press.

İnci, S. (2009). Türkiye sosyal bilgiler programının karşılaştırmalı incelemesi Kanada (Ontario), Irlanda, ABD (New York, Kaliforniya), Finlandiya, Yeni Zelanda. Yayımlanmamış yüksek lisans tezi, Kocaeli Üniversitesi Sosyal Bilimler Enstitüsü.

Kafadar, T., Öztürk, C. ve Katılmış, A. (2018). Farklı ülkelerin sosyal bilgiler öğretim programlarının değerler eğitimi boyutunda karşılaştırılması. Ahi Evran Üniversitesi Kırşehir Eğitim Fakültesi Dergisi, 19(1), 154-177.

Kan, Ç. (2009). Değişen değerler ve küresel vatandaşlık eğitimi. Kastamonu Eğitim Dergisi, 17(3), 895-904.

Kuş, Z. ve Aksu, A. (2017). Vatandaşlık ve vatandaşlık eğitimi hakkında sosyal bilgiler öğretmenlerinin inançları. Uluslararası Türk Ĕgitim Bilimleri Dergisi, $5(8), 18-41$.

Massey, K. (2014). Global citizenship education in a secondary geography course: The students' perspectives. Review of International Geographical Education Online, 4(2), 80-101.

MEB (2018a). Hayat bilgisi dersi öğretim programı ilköğretim 1, 2 ve 3. sinıflar. http://mufredat.meb.gov.tr/Programlar.aspx.

MEB (2018b). Insan haklarl, yurttaşlık ve demokrasi dersi öğretim programı (İlkokul 4. sinif). http://mufredat.meb.gov.tr/Programlar.aspx.

MEB (2018c). Sosyal bilgiler dersi öğretim programı ilkokul ve ortaokul (4, 5, 6 ve 7. sinfflar). http://mufredat.meb.gov.tr/Programlar.aspx.

Merey, Z. (2012). Türkiye ve ABD'deki sosyal bilgiler ders kitaplarında çocukların katılım haklarına yer verilme düzeyinin karşılaştırılması. Yayımlanmamış doktora tezi, Gazi Üniversitesi Eğitim Bilimleri Enstitüsü.

Merey, Z., Karatekin, K. ve Kuş, Z. (2012). İlköğretimde vatandaşlık eğitimi: Karşılaştırmalı kuramsal bir çalışma. Gazi University Journal of Gazi Educational Faculty (GUJGEF), 32(3), 795-821.

Mossberger, K., Tolbert, C. J. ve McNeal, R. S. (2008). Digital citizenship: The Internet, society, and participation. Cambridge, Massachusetts: The MIT Press.

Ontario Ministy of Education [OMOE]. (2007). Ontario First Nation, Métis, and Inuit education policy framework. 29.11.2019 tarihinde, www.edu.gov.on.ca/eng/aboriginal/fnmiframework.pdf

Ontario Ministy of Education [OMOE]. (2009). Ontario's equity and inclusive education strategy.

http://www.edu.gov.on.ca/eng/policyfunding/equity.pdf 
Ontario Ministy of Education [OMOE]. (2016). Ontario schools kindergarten to grade 12 policy and program requirements. 20.11.2019 tarihinde, http://www.edu.gov.on.ca/eng/document/policy/os/onschools_2016e.pdf

Ontario Ministy of Education [OMOE]. (2018). The Ontario curriculum social studies grades 1 to 6 history and geography grades 7 and 8 .

http://www.edu.gov.on.ca/eng/curriculum/elementary/social-studies-historygeography-2018.pdf

Ontario Ministy of Education [OMOE]. (2019). Indigenous education strategy. 20.11.2019 tarihinde, http://www.edu.gov.on.ca/eng/indigenous/

Özensel, E. (2012). Çokkültürlülük uygulaması olarak Kanada çokkültürlülügüü. Akademik Incelemeler Dergisi (AID), 7(1), 55-70.

Özkaral, T. C. (2015). Illkokul ve ortaokul düzeyinde sosyal bilgiler kapsamındaki ögretim programlarının karşılaştırmalı olarak incelenmesi. Yayımlanmamış doktora tezi, Necmettin Erbakan Üniversitesi Eğitim Bilimleri Enstitüsü.

Özkaral, T. C. (2019). Küresel ısınma ve iklim değişikliği konusunun Türkiye, Kanada (Ontario) ve Hong Kong sosyal bilgiler öğretim programlarında karş1laştırmalı olarak incelenmesi. International Journal of Education Technology and Scientific Researches, 4(8), 1-14.

Öztürk, T. ve Zayimoğlu-Öztürk, F. (2013). Kanada (Ontario) sosyal bilgiler öğretim programı ve bu programın Türkiye sosyal bilgiler öğretim programıyla karş1laştırılması. Adiyaman Üniversitesi Sosyal Bilimler Enstitüsü Dergisi Sosyal Bilgiler Öğretimi Özel Sayısı, 6(14), 485-514.

Ross, E. W. (2001). Remaking the social studies curriculum. E. W. Ross. (Ed.). Social studies curriculum: Purposes, problems, and possibilities içinde (s. 313-329). Albany: State University of New York Press.

Schugurensky, D. ve Myers, J. P. (2003). Citizenship education: Theory, research and practice. Encounters in Theory and History of Education, 4, 1-10.

Spellings, M. (2005). Helping your child become a responsible citizen. https://www2.ed.gov/parents/academic/help/citizen/citizen.pdf.

Talim Terbiye Kurulu Başkanlığı [TTKB]. (2019). Öğretim programları. 20.09.2020 tarihinde, http://mufredat.meb.gov.tr/Programlar.aspx.

Westheimer, J. ve Kahne, J. (2004). What kind of citizen? The politics of educating for democracy. American Educational Research Journal, 41(2), 237-269.

Yavuz, M. ve Özkaral, T. C. (2019). “Güç, otorite ve yönetim” temasının Türkiye, Kanada (Alberta) ve İngiltere sosyal bilgiler öğretim programlarında karşılaştırmalı olarak incelenmesi. Journal of Education and Future, 16, 51-63.

Yavuz, N., Duman, T. ve Karakaya, N. (2016). Insan haklarl ve demokrasi vatandaşlık bilgisi. Ankara: Pegem Yayınları.

Yıldırım, A. ve Şimşek, H. (2018). Sosyal bilimlerde nitel araştırma yöntemleri. Ankara: Seçkin Yayıncılık.

Yı1dırım, C. ve Türkoğlu, A. (2018). Karşılaştırmalı eğitim yansımaları: “On yıl sonra”. Adnan Menderes Üniversitesi Sosyal Bilimler Enstitüsü Dergisi, 5(1), 31-45. 